\title{
Perbedaan Waktu Pembekuan Darah Pasca Pencabutan Gigi pada Pasien Menopause dan Non-menopause
}

\author{
${ }^{1}$ Veren K. Turang \\ ${ }^{2}$ Lydia Tendean \\ ${ }^{1}$ P. S. Anindita \\ ${ }^{1}$ Program Studi Pendidikan Dokter Gigi Fakultas Kedokteran \\ ${ }^{2}$ Bagian Biologi Fakultas Kedokteran \\ Universitas Sam Ratulangi Manado \\ Email: Verenturang2@gmail.com
}

\begin{abstract}
Entering the age of 40s in women, hormone levels and alveolar bone density begin to decrease which can cause wobbly teeth ended with tooth extraction. In menopausal patient, the tooth extraction has to be performed very carefully to avoid excessive bleeding. This study was aimed to compare the clotting time after tooth extraction of menopausal patients with of non-menopausal patients at RSGM Unsrat Manado. This was an analytical descriptive study with a cross sectional design. Study population included all female patients aged 35-60 years who had tooth extraction performed on them at the Oral Surgery Department of RSGM Unsrat in June 2018. Samples were obtained by using the total sampling method. The results showed that there were 32 subjects consisted of 13 women (40.63\%) aged 35-44 years (nonmenopause) and 19 women (59.37\%) aged 45-60 tahun (menopause). Most of the normal clotting timess of non-menopausal subjects were at minutes-6 and 7, each of 5 subjects (15.62\%). Most of the abnormal clotting times in menopausal subjects was at minute-9 as many as 8 subjects $(25.00 \%)$. The Shapiro-Wilk test showed that data were not distributed normally; therefore, the further analysis was performed with the Mann-Whitney test with a $P$ value of $0.000(P<0.05)$. Conclusion: There was a significant difference in clotting time after tooth extraction between menopausal and non-menopausal patients.
\end{abstract}

Keywords: menopause, non menopause, clotting time, tooth extraction

\begin{abstract}
Abstrak: Memasuki usia 40-an kadar hormon pada perempuan mulai berkurang, demikian pula kepadatan tulang alveolar yang dapat menyebabkan kegoyangan gigi dan dilakukannya tindakan pencabutan gigi. Pada pasien menopause teknik pencabutan gigi harus dilakukan secara hati-hati untuk mengurangi risiko perdarahan berlebihan. Penelitian ini bertujuan untuk mengetahui perbedaan waktu pembekuan darah pasca pencabutan gigi antara pasien menopause dan non-menopause di RSGM Unsrat Manado. Jenis penelitian ialah deskriptif analitik dengan desain potong lintang. Populasi penelitian yaitu semua pasien perempuan berusia 3560 tahun yang dilakukan tindakan pencabutan gigi di Bagian Bedah Mulut RSGM Unsrat pada bulan Juni 2018. Pengambilan sampel menggunakan metode total sampling. Hasil penelitian menda-patkan 32 orang subyek penelitian, terdiri dari 13 orang $(40,63 \%)$ berusia $35-44$ tahun (non-menopause) dan 19 orang $(59,37 \%)$ berusia 45-60 tahun (menopause). Kategori waktu pembe-kuan normal pada subyek non-menopause terbanyak pada menit ke-6 dan ke-7, masing-masing sebanyak 5 orang $(15,62 \%)$. Kategori tidak normal pada subyek menopause terbanyak pada menit ke-9 sebanyak 8 orang $(25,00 \%)$. Hasil uji Shapiro-Wilk menunjukkan data terdistribusi tidak normal, dan dilanjutkan dengan uji Mann-Whitney dengan perolehan signifikansi $0,000(P<0,05)$. Simpulan: Terdapat perbedaan bermakna pada waktu pembekuan darah pasca pencabutan gigi antara pasien menopause dan non menopause.
\end{abstract}

Kata kunci: menopause, non menopause, waktu pembekuan darah, pencabutan gigi 
Perkembangan dan pertumbuhan manusia berjalan seiring dengan bertambahnya usia dan akan terhenti pada satu tahap dimana terjadi penurunan fungsi tubuh. Perubahan tersebut paling banyak terjadi pada perempuan karena pada proses penuaan terjadi suatu fase yaitu menopause. ${ }^{1}$

Populasi perempuan menopause di Indonesia cenderung semakin tinggi. Data Departemen Kesehatan memperlihatkan bahwa perempuan Indonesia mengalami menopause sebesar $7,4 \%$ dari populasi pada tahun 2000 dan diperkirakan akan meningkat menjadi $14 \%$ atau sekitar 30 juta orang pada tahun 2015. Umumnya peningkatan populasi perempuan menopause akan disertai permasalahan kompleks yang berdampak pada peningkatan masalah kesehatan perempuan menopause tersebut. ${ }^{2}$

Menopause merupakan suatu keadaan alamiah yang berlangsung secara fisiologis dalam perjalanan hidup seorang perempuan. ${ }^{3}$ Pada keadaan ini reproduksi perempuan berakhir yang disebabkan menurunnya hormon estrogen dan progesteron ditandai dengan berhentinya menstruasi yang menandakan berakhirnya kesuburan. ${ }^{4}$ Menopause pada kehidupan perempuan dapat memengaruhi kesehatan gigi dan mulut karena pada masa ini biasanya terjadi gangguan keseimbangan fungsi hormon. ${ }^{5}$ Memasuki usia 40-an hormon-hormon pada perempuan serta kepadatan tulang alveolar mulai berkurang yang dapat menyebabkan kegoyangan gigi. ${ }^{4,5}$ Pada usia ini pasien yang dilakukan tindakan pencabutan gigi merupakan kasus terbanyak. ${ }^{6}$

Kehilangan gigi akibat pencabutan merupakan masalah yang sering terjadi pada masyarakat. ${ }^{7}$ Kesehatan gigi dan mulut dapat memengaruhi kesehatan tubuh secara keseluruhan. ${ }^{8}$ Pencabutan gigi merupakan tindakan mengeluarkan gigi dari soket tulang alveolar yang menimbulkan luka dan menyebabkan perdarahan.

Pada pasien menopause teknik pencabutan gigi dilakukan secara hati-hati untuk mengurangi perdarahan yang berlebihan ${ }^{9}$ karena pada menopause terjadi penurunan kadar hormon estrogen dan progesteron serta kalsium. Penurunan hormon estrogen mengakibatkan vasomotor tidak stabil, gangguan pada psikis seperti ansietas, depresi, serta timbulnya gangguan metabolisme dari tubuh perempuan itu sendiri. Juga terjadi atrofi pada jaringan ikat serta pembuluh darah mukosa dan kulit sehingga aliran darah berkurang, yang berakibat pasokan darah berkurang dan proses penyembuhan luka terhambat. Estrogen memengaruhi proses pembekuan darah dengan menghambat respon lokal peradangan melalui macrophage inhibitor factor (MIF) sehingga mengakibatkan peradangan berlebihan dan waktu yang diperlukan darah untuk membeku menjadi lebih lama. ${ }^{6,10}$ Hormon progesteron menghambat kerja estrogen pada jaringan tertentu. Pada perempuan yang anovulatori, tidak ada korpus luteum terbentuk; oleh karena itu kerja estrogen sering tidak terhalangi. $^{10}$ Kalsium berperan penting dalam proses fisiologis yang meliputi pembekuan darah. Penurunan kadar kalsium dalam darah dapat menyebabkan terganggunya proses pembekuan darah yaitu darah tidak dapat membeku pada saat terjadi luka. $^{11}$

Survei awal yang dilakukan penulis menunjukkan bahwa terdapat banyak kasus pencabutan gigi pada kartu rekam medik di RSGM Universitas Sam Ratulangi Manado. Penelitian ini bertujuan untuk membandingkan perbedaan waktu pembekuan darah pasca pencabutan gigi pada pasien menopause dan non-menopause di RSGM Universitas Sam Ratulangi Manado.

\section{METODE PENELITIAN}

Jenis penelitian yaitu deskriptif analitik dengan desain potong lintang. Penelitian dilaksanakan di Rumah Sakit Gigi dan Mulut (RSGM) Universitas Sam Ratulangi pada bulan Juni-Juli 2018. Populasi penelitian ialah semua pasien perempuan berusia 35-60 tahun yang dilakukan tindakan pencabutan gigi di Bagian Bedah Mulut RSGM Unsrat pada bulan Juni-Juli 2018 yang berjumlah 150 pasien. Penelitian ini menggunakan total sampling.

Menopause yaitu fase berakhirnya siklus menstruasi seorang perempuan yang 
disebabkan oleh menurunnya fungsi hormon yang terjadi pada usia 45-60 tahun sedangkan non-menopause yaitu seorang perempuan yang siklus menstruasinya masih berjalan normal setiap bulannya terjadi pada usia 35-44 tahun. Waktu pembekuan darah pasca pencabutan gigi dinilai dengan melakukan pemeriksaan waktu pembekuan (clotting time) dan dikategorikan normal jika waktu pembekuan darah pasien 4-8 menit dan tidak normal jika $>8$ menit.

Alat dan bahan yang digunakan dalam penelitian ini ialah pinset, stopwatch, alat tulis menulis, masker, sarung tangan steril, piala ginjal, kamera digital, tampon, tisu.

Lembar informed consent harus ditandatangani oleh pasien itu sendiri. Pasien dipersilahkan untuk masuk ke ruangan bedah mulut dan duduk di dental unit dan pencabutan gigi dilakukan oleh operator. Pada saat operator telah selesai melakukan tindakan pencabutan gigi, pasien diinstruksikan untuk menggigit tampon dan peneliti segera melakukan pemeriksaan waktu pembekuan darah dengan mengamati socket pasca pencabutan gigi pada pasien dan menentukan waktu pembekuan menggunakan stopwatch, apakah normal atau tidak normal. Selesai pemeriksaan dan tindakan, pasien dipersilahkan untuk menggigit tampon yang sudah disediakan.

Data penelitian diproses dengan editing dan data entry dan dianalisis menggunakan Statistical Product and Service Solutions (SPSS). Analisis perbedaan waktu pembekuan darah pasca pencabutan gigi pada pasien menopause dan non menopause di RSGM Unsrat dengan menggunakan uji normalitas Shapiro-wilk. Bila data tidak terdistribusi normal dilakukan uji Mann Whitney Test dan bila data terdistribusi normal maka digunakan uji t.

\section{HASIL PENELITIAN}

Penelitian dilaksanakan di RSGM Unsrat berlokasi di Jl. Dr. Sutomo no. 3 pusat Kota Manado. RSGM dikelola oleh Universitas Sam Ratulangi yang merupa- kan wahana pendidikan profesi dokter gigi. RSGM memberikan berbagai pelayanan seperti pencabutan gigi, penambalan gigi, pembuatan gigi palsu, pembersihan karang gigi, pembuatan alat ortodontik, dll yang ditangani oleh mahasiswa co-ass dibawah bimbingan dokter gigi yang merupakan dosen Unsrat serta tenaga dokter gigi anggota Persatuan Dokter Gigi Indonesia (PDGI) Cabang Manado.

Tabel 1 menunjukkan distribusi karakteristik subyek penelitian berdasarkan usia. Subyek yang berusia 35-44 tahun berjumlah 13 orrang $(40,63 \%)$ sedanfgkan yang berusia 45-60 tahun berjumlah 19 orang $(59,37 \%)$.

Tabel 1. Distribusi karakteristik subyek penelitian berdasarkan usia

\begin{tabular}{ccc}
\hline Usia (tahun) & $\mathbf{N}$ & $\mathbf{\%}$ \\
\hline $35-44$ & 13 & 40,63 \\
$45-60$ & 19 & 59,37 \\
Total & 32 & 100 \\
\hline
\end{tabular}

Tabel 2 memperlihatkan bahwa dari 32 subyek dengan kategori normal paling sedikit yaitu pada waktu pembekuan darah menit ke-8 sebanyak 2 orang $(6,26 \%)$. Kategori tidak normal paling sedikit yaitu pada waktu pembekuan darah menit ke-10 yaitu sebanyak 3 orang $(9,38 \%)$.

Tabel 3 menunjukkan perbedaan waktu pembekuan darah pasien menopause dan non menopause di RSGM. Dari 32 subyek yang menunjukkan kategori normal (non menopause) terbanyak pada menit ke-6 dan ke-7 masing-masing sebanyak 5 orang $(15,62 \%)$. Kategori tidak normal (menopause) terbanyak yaitu pada menit ke-9 sebanyak 8 orang $(25,00 \%)$.

\section{BAHASAN}

Penelitian ini dilakukan di RSGM Universitas Sam Ratulangi Manado selama 5 hari pada pukul 09.00-14.00 WITA. Berdasarkan hasil penelitian didapatkan subyek penelitian berjumlah 32 orang perempuan: 14 orang $(43,75 \%)$ berusia 35 44 tahun dan 18 orang $(56,25 \%)$ berusia 45 60 tahun. 
Turang, Tendean, Anindita: Perbedaan waktu pembekuan darah ...

Tabel 3. Distribusi karakteristik subyek berdasarkan lamanya waktu pembekuan darah

\begin{tabular}{cccc}
\hline $\begin{array}{c}\text { Waktu pembekuan } \\
\text { darah (menit) }\end{array}$ & $\begin{array}{c}\text { Kategori } \\
\text { pembekuan darah }\end{array}$ & N & \% \\
\hline 5 & Normal & 4 & 12,50 \\
6 & Normal & 5 & 15,62 \\
7 & Normal & 5 & 15,62 \\
8 & Normal & 2 & 6,26 \\
9 & Tidak normal & 8 & 25 \\
10 & Tidak normal & 3 & 9,38 \\
11 & Tidak normal & 5 & 15,62 \\
Total & & 32 & 100 \\
\hline
\end{tabular}

Tabel 4. Perbedaan waktu pembekuan darah pasien menopause dan non menopause

\begin{tabular}{cccccccc}
\hline $\begin{array}{c}\text { Waktu pembekuan } \\
\text { darah (menit) }\end{array}$ & \multicolumn{2}{c}{$\begin{array}{c}\text { Normal (non- } \\
\text { menopause) }\end{array}$} & \multicolumn{2}{c}{$\begin{array}{c}\text { Tidak normal } \\
\text { (menopause) }\end{array}$} & Total & $\boldsymbol{P}$ \\
\cline { 2 - 8 } & $\mathrm{N}$ & $\%$ & $\mathrm{~N}$ & $\%$ & $\mathrm{~N}$ & $\%$ & \\
\hline 5 & 4 & 12,5 & 0 & 0 & 4 & 12,5 & \\
6 & 5 & 15,62 & 0 & 0 & 5 & 15,62 & \\
7 & 5 & 15,62 & 0 & 0 & 5 & 15,62 & \\
8 & 2 & 6,25 & 0 & 0 & 2 & 6,25 & 0,000 \\
9 & 0 & 0 & 8 & 25,00 & 8 & 25,00 & \\
10 & 0 & 0 & 3 & 9,38 & 3 & 9,38 & \\
11 & 0 & 0 & 5 & 15,62 & 5 & 15,62 & \\
\hline
\end{tabular}

Di Indonesia perempuan yang mengalami menopause dimulai sejak usia 45-60 tahun sedangkan yang berusia 35-44 tahun masih mengalami masa reproduksi atau non menopause, ${ }^{12}$ namun dalam hasil penelitian yang telah dilakukan ditemukan 3 subyek dengan usia 45 tahun, 47 tahun, dan 49 tahun yang belum mengalami menopause. Terdapat beberapa faktor yang memengaruhi usia memasuki menopause di antaranya usia sewaktu mendapat menstruasi pertama kali (menarche), kondisi kejiwaan dan pekerjaan, jumlah anak, penggunaan obat-obatan keluarga berencana (KB), merokok, cuaca, dan ketinggian tempat tinggal dari permukaan laut. ${ }^{13}$ Penelitian ini tidak sejalan dengan penelitian yang dilakukan oleh Senolinggi et al. ${ }^{14}$ di Kecamatan Kakas Sulawesi Utara yang menyatakan usia rata-rata perempuan mengalami menopause di mulai dari usia 45 tahun karena pada usia ini mulai mengalami penurunan fungsi hormon. ${ }^{26}$

Hasil penelitian berdasarkan lamanya waktu pembekuan darah yaitu 5-8 menit sebanyak 16 subyek (50\%). Dalam pene- litian ini terdapat 3 subyek dengan usia 45, 47 dan 49 tahun (usia menopause) yang belum mengalami menopause dengan waktu pembekuan darah dikategorikan normal. Waktu pembekuan darah pada pasien non-menopause dikategorikan normal karena belum terjadi penurunan fungsi hormon estrogen, progesteron, dan kadar kalsium. Penelitian ini sejalan dengan Prihadi ${ }^{15}$ di Semarang yang menyatakan bahwa waktu pembekuan darah 5-8 menit masuk dalam kategori normal. Hal ini juga didukung dengan penelitian yang dilakukan oleh Luvriani ${ }^{16}$ yang menyatakan jika masa pembekuan >2,5 kali nilai normal, maka potensial terjadi perdarahan. Normalnya darah membeku dalam 4-8 menit (Metode Lee White). Berdasarkan lamanya waktu pembekuan darah pada menit ke 9-11 didapatkan sebanyak 16 subyek (50\%). Penelitian ini sejalan dengan Prihadi ${ }^{15}$ di Semarang yang menyatakan bahwa waktu pembekuan darah jika lebih dari 8 menit dikategorikan tidak normal.

Hasil uji perbedaan waktu pembekuan darah pasca pencabutan gigi pada pasien 
menopause dan non-menopause menggunakan uji Shapiro-Wilk menunjukkan data tidak terdistribusi normal, sehingga uji parametrik $\mathrm{T}$ tidak berpasangan tidak dapat digunakan. Analisis statistik dilanjutkan dengan uji non-parametrik Mann-Whitney dan diperoleh angka signifikan $0,000(P<$ $0,05)$ yang menunjukkan terdapat perbedaan bermakna waktu pembekuan darah pasca pencabutan gigi pada pasien menopause dan non menopause.

Hasil penelitian ini sejalan dengan penelitian oleh Parmasari et al. ${ }^{6}$ di Surabaya yang melaporkan bahwa perbandingan waktu pembekuan darah antara menopause dan non-menopause menunjukkan waktu pembekuan darah pada wanita menopause yang lebih panjang. Hal ini dikarenakan pada wanita menopause telah terjadi penurunan fungsi hormon estrogen, progesteron, dan kadar kalsium.

Permeriksaan waktu pembekuan darah dapat juga dilakukan dengan menggunakan metode slide untuk mendapatkan hasil waktu yang lebih akurat. Penelitian menggunakan metode slide dilakukan di Laboratorium dengan alat dan bahan yang lebih lengkap, ${ }^{16}$ sedangkan penelitian yang dilakukan ini menggunakan alat dan bahan sederhana untuk mengukur clotting time.

\section{SIMPULAN}

Berdasarkan hasil penelitian ini dapat disimpulkan bahwa terdapat perbedaan bermakna dari waktu pembekuan darah pasca pencabutan gigi antara pasien menopause dan non menopause di RSGM Unsrat. Lamanya waktu pembekuan darah pasca pencabutan gigi pada pasien menopause lebih panjang dibandingkan dengan pasien non menopause.

\section{SARAN}

Diharapkan dapat dilakukan penelitian lebih lanjut untuk mengetahui perbedaaan waktu pembekuan darah pada pasien menopause dan non menopause dengan menggunakan metode slide karena metode slide lebih efektif dan akurat dalam penentuan clotting time.

\section{DAFTAR PUSTAKA}

1. Diniyati, Heriyani N, Herwani N. Hubungan pengetahuan dengan sikap perempuan premenopause menghadapi perubahan pada masa menopause di Kelurahan Buluran Kenali Kota Jambi tahun 2016. PANNMED. 2016;11(1):17-22.

2. Suparni IE, Trisnawati Y. Hubungan gangguan masa menopause dengan tingkat kecemasan pada ibu menopause di Desa Dawuhan Kecamatan Purwoasri Kabupaten Kediri. Edu Health. 2014;4(2):90-8.

3. Ghani L. Seluk beluk menopause. Media Litbangkes. 2009;19(4):193-7.

4. Minoroh S, Mahmudah. Faktor yang berpengaruh terhadap skor kecemasan pada wanita menopause. Jurnal Biometrika dan Kependudukan. 2013; 2(1):51-6.

5. Kusdhani L, Mulyono G, Basaka ES, Oemardi M, Rahardjo BTW. Kualitas tulang mandibula pada wanita pasca menopause. JKGUI. 2008;7: 673-8.

6. Parmasari WD, Theodora, Willianti E. Hubungan antara menopause dengan proses penyembuhan luka pasca pencabutan gigi di Poli Gigi Universitas Wijaya Kusuma Surabaya. Ilmiah Kedokteran. 2016;5(1):49-57.

7. Agtini MD. Persentase pengguna protesa di Indonesia. Media Litbangkes. 2010; 20(2):50-8.

8. Basuni, Cholil, Putri DKT. Gambaran indeks kebersihan mulut berdasarkan tingkat pendidikan masyarakat di Desa Guntung Ujung Kabupaten Banjar. Dentino. 2014;2(1):18-2.

9. Rahman KM, Amir D, Noer M. Efek pencabutan gigi terhadap peningkatan tekanan darah pada pasien hipertensi. Jurnal Kesehatan Andalas. 2017;6(1).

10. Norhalifa, Rahmawanty D, Nurlely. Uji efektivitas ekstrak air ikan haruan (Channa Striata) asal Kalimantan Selatan terhadap bleeding time dan clotting time secara in vivo. Media Farmasi. 2016;13(2):237-49.

11. Dewi MIK, Sarihati ID, Widhya DHS. Gambaran kadar kalsium darah pada wanita menopause di Banjar Binoh Kaja, Desa Ubung Kaja, Kecamatan Denpasar Utara. Meditory 2016;4(2): 127-34.

12. Sepduiana H. Usia menopause pada wanita di wilayah kerja Puskesmas Rambah 
Turang, Tendean, Anindita: Perbedaan waktu pembekuan darah ...

Kabupaten Rokan Hulu. Maternity and Neonatal. 2016;2(2):146.

13. Spencer RF, Brown P. Menopause. Jakarta: Erlangga, 2007; p. 8, 9,14, 16.

14. Senolinggi AM, Mewengkang M, Wantania $\mathbf{J}$. Hubungan antara usia menarche dengan usia menopause pada wanita di Kecamatan Kakas Sulawesi Utara tahun 2014. eCl. 2014;3(1):142.

15. Prihadi H. Pemeriksaan masa pembekuan darah (clotting time) [Skripsi].
Semarang: Fakultas Kedokteran Universitas Diponegoro; 2008.

16. Luvriani E, Pramudianti MID, Pramonodjati F. Perbandingan hasil pemeriksaan masa pembekuan darah (clotting time) metode slide dengan metode tabung (modifikasi Lee White) [Skripsi]. Surakarta: Fakultas Ilmu Kesehatan Universitas Setia Budi; 2014. 